\title{
Demokrasi Agonistik dan Spirit Baru Pasca-Pilkada
}

\author{
Agonistic Democracy and the Postelection New Spirit
}

\author{
Ferdi Jehalut \\ Alumnus STFK Ledalero \\ E-mail: djehalutferdinst@gmail.com
}

\begin{abstract}
The simultaneous general election of district heads in 270 regencies, municipalities and provinces in Indonesia in 2020 has ended. The end of the simultaneous general elections does not mean the end of competition, debate and discourse in democracy. A living democracy needs constant contestation, debate and discourse. That is the essence of the idea of agonistic democracy. The idea of agonistic democracy will be discussed in a sharp and comprehensive manner in this paper. Thus, the aim of this paper is to explain the concept of agonistic democracy. Furthermore, starting from the idea of agonistic democracy, the writer will show what spirit needs to be nurtured after the simultaneous regional elections that have just been held. The approach used in this paper is a speculative-analysis approach.
\end{abstract}

Keywords: Politics, Political, Agonistic Democracy, and Confrontation

\begin{abstract}
Abstraksi
Pilkada serentak di 270 daerah di Indonesia pada tahun 2020 telah berakhir. Berakhirnya pemilihan umum serentak itu tidak berarti berakhir pula persaingan, perdebatan, dan diskursus dalam demokrasi. Demokrasi yang hidup justru membutuhkan kontestasi, perdebatan, dan diskursus terus-menerus. Itulah inti gagasan demokrasi agonistik. Gagasan demokrasi agonistik ini akan diulas secara tajam dan komprehensif dalam tulisan ini. Dengan demikian, tujuan tulisan ini ialah menjelaskan konsep demokrasi agonistik. Selanjutnya, bertolak dari gagasan demokrasi agonistik itu, penulis akan memperlihatkan spirit apa yang perlu dibangun pasca-Pilkada serentak yang baru saja digelar. Pendekatan yang digunakan dalam tulisan ini ialah pendekatan analisis-spekulatif.
\end{abstract}

Kata-kata kunci: Politik, Yang Politis, Demokrasi Agonistik, dan Konfrontasi

\section{Pendahuluan}

Pilkada serentak di 270 daerah di Indonesia pada tahun 2020 telah selesai. Sebagai salah satu prestasi desentralisasi, Pilkada menjadi momentum untuk membangun kekuatan politik yang berorientasi pada kesejahteraan umum. Kesejahteraan umum hanya tercapai jika para pemimpin yang terpilih dalam proses Pilkada mampu mengorganisasi kekuasaan secara baik dan bertanggung jawab. Pengorganisasian kekuasaan secara baik dan bertanggung jawab tidak hanya mengandalkan kolaborasi, tetapi juga butuh konfrontasi.

Konfrontasi itu penting. Selain untuk menjaga agar ruang politik tetap eksis, konfrontasi juga dibutuhkan agar para pemimpin tidak merawat kemalasan berpikir. Sebab dengan adanya konfrontasi para pemimpin dirangsang untuk terus berpikir alternatif dan out of the box. Mereka ditantang untuk tidak berpikir biasa-biasa saja. Dalam konteks ini, pilkada dimaknai bukan sebagai selebrasi formal (prosedural) 
semata, melainkan juga sebagai momentum untuk merawat substansi demokrasi dan yang politis (the political).

Secara substansial yang politis merupakan medan konflik, perjuangan, kontestasi, dan antagonisme. Konflik, perjuangan, kontestasi, dan antagonisme mengandaikan keberadaan dua atau lebih agen atau subjek yang saling bersaing untuk merebut pengaruh dan meraih kemenangan. Untuk merebut pengaruh dan meraih kemenangan masing-masing agen atau subjek harus siap menguras tenaga untuk berpikir. Mereka bersaing dalam strategi dan bertengkar dalam ide, tetapi tetap akrab sebagai warga negara. Inilah cita rasa demokrasi yang sebenarnya. Demokrasi yang autentik dan radikal senantiasa menghargai pluralisme. Penerimaan atas pluralisme melegitimasi perjuangan, kontestasi, perbedaan, konflik, kebebasan, dan kesetaraan politik bagi semua.

Ulasan di atas sebenarnya mau menunjukkan bahwa demokrasi tidak boleh hanya berhenti pada tataran formal (prosedural) yang tampak dalam pemilu yang dilakukan secara berkala. Demokrasi harus bergerak melampaui itu. Demokrasi harus menyentuh akar atau substansinya, yakni berkaitan dengan penataan simbolik relasi-relasi sosial.

Tulisan berikut bertujuan menjelaskan lebih komprehensif pandangan di atas dan memperlihatkan apa konsekuensinya bagi keberlangsungan demokrasi di Indonesia pasca-Pilkada. Seluruh elaborasi dalam tulisan ini berpijak pada pemikiran Chantal Mouffe (1943-sekarang), seorang filsuf politik postrukturalisme berkebangsaan Belgia. Tesis dasar yang hendak dibela dalam tulisan ini ialah: pertama, politik demokrasi butuh konfrontasi. Dasarnya ialah demokrasi tidak harus selalu berorientasi pada pencapaian konsensus final dan universal. Demokrasi yang hidup juga butuh perjuangan agonistik. Itu berarti demokrasi juga harus menyediakan kondisi bagi disensus dan konsensus konfliktual. Inilah inti gagasan demokrasi agonistik yang akan diulas secara komprehensif dalam tulisan ini. Kedua, demokrasi tidak boleh hanya berhenti pada tataran formal (prosedural) yang tampak dalam pemilu yang dilaksanakan secara periodik. Demokrasi harus menyentuh substansinya. Substansi demokrasi itulah yang diharapkan tetap dirawat pasca-Pilkada.

\section{Politik dan Yang Politis}

Sebelum mengulas lebih jauh pandangan Chantal Mouffe tentang demokrasi agonistik, terlebih dahulu dijelaskan mengenai dua term kunci dalam teori demokrasi Chantal Mouffe. Kedua term itu ialah politik dan yang politis.

Mouffe membuat distingsi antara politik (politics) dan political atau yang politis (the political). Dalam bahasa seharihari memang orang hampir tidak pernah berbicara tentang yang politis. Bahkan, batasan antara politik dan yang politis tampak kabur. Akan tetapi, bagi Mouffe, sebagaimana ditunjukkannya dalam buku On the Political, secara teoretis dan konseptual distingsi antara politik dan yang politis penting dibuat untuk membuka jalan bagi refleksi yang lebih mendalam tentang politik. Hal ini juga pernah dibuat oleh para ahli teori politik lain, meskipun tidak ada kata sepakat di antara mereka tentang makna dan arti dari term-term itu.

Pada umumnya ada dua pendekatan yang dapat memberikan orientasi bagi telaah lebih lanjut tentang pemahaman politik dengan yang politis. Dua jenis pendekatan itu ialah pertama, ilmu politik (political science) yang berkaitan dengan bidang empiris dari politik (politics), kedua, teori politik yang merupakan domain para filsuf yang mempertanyakan bukan fakta-fakta 
politik (politics), melainkan esensi dari yang politis (the political). Secara filosofis, distingsi ini digambarkan oleh Heidegger demikian: politik (politics) mengacu pada tingkat ontis, sedangkan yang politis (the political) mengacu pada tingkat ontologis. Yang ontis berhubungan dengan bermacammacam praktik politik konvensional, sedangkan yang ontologis berhubungan dengan cara pelembagaan masyarakat (Chantal Mouffe, 2005: 8-9).

Kendatipun Heidegger telah menunjukkan perbedaan semacam itu, kemungkinan ketidaksetujuan mengenai apa yang membentuk yang politis (the political) tetap ada. Hannah Arendt misalnya, melihat yang politis sebagai ruang kebebasan dan deliberasi publik (Chantal Mouffe, 2005: 89). Bagi Arendt, yang politis itu baru terbentuk ketika manusia berkomunikasi satu sama lain. Dengan demikian, untuk Arendt, subjek tunggal (baca: manusia man) itu tidak politis. Yang politis itu adalah subjek-subjek (baca: manusia-manusia men). Dengan kata lain, tidak ada manusia yang dari kodratnya bersifat politis sebagaimana dipahami oleh Aristoteles dengan istilah zoon politicon. Political berada di antara manusia-manusia. Ia baru terbentuk ketika manusia berkomunikasi atau berdeliberasi. Maka, setiap upaya untuk mengeliminasi komunikasi dan deliberasi di ruang publik dipandang sebagai antipolitik. Suasana antipolitik hanya terbentuk dalam kondisi penguasaan atau dominasi. Dengan demikian, rezim otoritarianisme Orde Baru dalam kerangka pemikiran Arendt adalah rezim antipolitik atau rezim tanpa politik (political).

Berbeda dengan Arendt, pemikir lain seperti Schmitt, justru melihat yang politis (political) sebagai ruang kekuasaan (space of power), konflik, dan antagonisme (Chantal Mouffe, 2005: 9; Carl Schmitt, 2007: 26-27). Schmitt rupanya juga dipengaruhi oleh Heidegger yang melihat konflik sebagai sesuatu yang permanen dalam political. Heidegger sendiri mengambil inspirasi dari fragmen 53 Heraklitos yang berbunyi: "Polemos (konflik) adalah ayah bagi semua yang ada" (Donny Gahral Adian, 2010: 2). Jadi, baik Schmitt maupun Heidegger melihat yang politis sebagai medan konflik dan bukan sebagai medan pencapaian konsensus. Secara implisit, bagi keduanya, setiap upaya untuk mencapai konsensus dalam ranah politik (the political) menghilangkan karakter yang politis itu sendiri. Dalam konteks ini, proyek Rawls dan Habermas serta para pengikut mereka dipandang menghancurkan atau melenyapkan the political.

Pemahaman Mouffe tentang the political mengikuti pandangan yang terakhir di atas. Lebih jauh ia membedakan antara yang politis (the political) dan politik (politics). Yang politis bagi Mouffe merupakan dimensi antagonisme yang merupakan konstitutif bagi masyarakat manusia. Dengan kata lain, antagonisme ini merupakan sesuatu yang inheren dalam relasi-relasi manusia. Antagonisme dapat mengambil banyak bentuk dan muncul di dalam jenis-jenis yang berbeda dari relasirelasi sosial. Sedangkan politik (politics) merupakan serangkaian praktik, wacana, dan institusi yang dapat menciptakan keteraturan dan mengorganisasi koeksistensi manusia dalam konteks konfliktualitas yang disediakan oleh the political (Chantal Mouffe, 2005: 9, 2000: 101).

Lebih lanjut, Mouffe (2000: 101) menegaskan bahwa hanya ketika dimensi yang politis diakui dan politik dipahami sebagai upaya menjinakkan permusuhan dan meredakan potensi pertentangan yang ada dalam hubungan manusia, pertanyaan sentral untuk demokrasi dapat diajukan. Pertanyaannya tidak dirumuskan dalam formula kaum rasionalis, yakni bagaimana mencapai konsensus tanpa pengucilan 
(eksklusi). Pertanyaan semacam ini menyiratkan pemberantasan politik. Padahal, politik bertujuan menciptakan persatuan dalam konteks konflik dan keragaman. Hal itu mengandaikan penciptaan "kita" dengan determinasi "mereka".

Bertolak dari penjelasan di atas, tujuan Mouffe membuat distingsi antara politik dan yang politis bersifat politis. Mouffe hendak menunjukkan bahwa hegemoni liberalisme yang tak tertandingi saat ini terjadi karena orang tidak sanggup berpikir secara politis, yakni memahami the political dalam dimensi ontologisnya. Secara ontologis the political bersifat konfliktual dan antagonistik. Pandangan Schmitt tentang politik yang ditulisnya dalam The Concept of the Political membantu Mouffe untuk menangkap karakter itu.

Dalam The Concept of the Political (2007: 26-27), Schmitt menegaskan bahwa definisi the political hanya bisa didapatkan dengan menemukan dan mendefiniskan secara spesifik kategori political. Yang spesifik dari kategori political ialah distingsi antara kawan (friend) dan musuh (enemy). Semua tindakan dan tujuan-tujuan politik bisa direduksi ke dalam distingsi kawan dan musuh ini. Inilah hakikat political yang berbeda dari ranah moralitas, estetika, dan ekonomi. Dalam bidang moralitas terdapat distingsi antara baik (good) dan jahat (evil); dalam bidang estetika terdapat distingsi antara indah/cantik (beautiful) dan buruk (ugly); dan dalam bidang ekonomi terdapat disingsi antara menguntungkan (profitable) dan tidak menguntungkan (unprofitable). Distingsi kawan dan musuh ini menurut Schmitt sepenuhnya menunjukkan derajat intensitas penyatuan dan pemisahan, perkumpulan dan peruraian dalam politik

Lalu, siapakah musuh politik dalam pandangan Schmitt? Bagi Schmitt (2007: 27), musuh politik ialah 'yang lain' (the other), 'yang asing' (the stranger). Yang lain atau yang asing itu tidak perlu jahat secara moral atau buruk secara estetika. Dia juga tidak perlu tampil sebagai pesaing ekonomi, dan bahkan mungkin menguntungkan untuk terlibat dengannya dalam transaksi bisnis. Secara eksistensial, yang lain itu sesuatu yang berbeda dan asing. Oleh karena itu, pertikaian dengannya mungkin terjadi. Namun, pertikaian itu tidak dapat diselesaikan oleh norma umum yang ditentukan sebelumnya atau dengan penilaian pihak ketiga yang tidak tertarik dan karenanya netral. Hanya para peserta aktuallah yang dapat menyelesaikan konflik atau pertikaian itu. Sebab mereka dapat dengan benar mengenali, memahami, dan menilai situasi konkret. Dalam penilaian itu, setiap peserta bebas memutuskan apakah cara hidup musuhnya itu harus ditolak dan dilenyapkan ataukah dibiarkan tetap ada. Meskipun demikian, menurut Schmitt, secara emosional musuh itu mudah untuk diperlakukan sebagai yang jahat dan buruk, dan karena itu berpotensi untuk dilenyapkan. Mouffe menggunakan distingsi Schmitt di atas untuk menjelaskan karakter dari yang politis (the political). Distingsi Schmitt membantu dia untuk mengenali hakikat konfliktual dan antagonistik dari yang politis. Meskipun demikian, ia tidak menelan mentah-mentah pemikiran Schmitt. Mouffe justru berusaha berpikir bersama Schmitt melawan Schmitt. Mouffe melihat ada karakter otoritarian dalam pemikiran Schmitt dengan menempatkan musuh sebagai yang berpotensi untuk dilenyapkan atau dihabisi. Oleh karena itulah Mouffe membuat konversi musuh (enemy) dalam distingsi Schmitt menjadi lawan (adversary). Dengan konversi ini status musuh bukan lagi sebagai the other yang harus dihabisi, melainkan justru harus dilindungi keberadaannya. Relasi antagonistik pun berubah menjadi relasi agonistik. Dalam relasi agonistik siapapun yang mengidentifikasikan dirinya sebagai kawan selalu terikat tanggung jawab untuk 
melindungi lawannya. Di sinilah, hemat penulis, tampak pengaruh Emanuel Levinas terhadap Mouffe. Bagi Levinas, penampakan yang lain (the other) di hadapan kita serentak memberikan imperatif kepada kita untuk mau tidak mau harus bertanggung jawab terhadapnya. Etika Levinas ini diterapkan oleh Mouffe dalam politik untuk merawat ke-lyan-an dan pluralitas dalam politik.

Ada beberapa signifikansi dari konversi yang dibuat Mouffe di atas. Pertama, dengan mengubah status musuh menjadi lawan, Mouffe hendak keluar dari lingkaran pemikiran otoritarian Schmitt. Konstruksi teoretis Schmitt itu secara inheren menjustifikasi kekerasan dalam politik. Maka tidak mengherankan jika banyak orang menilai pandangan Schmitt tidak kompatibel dengan logika demokrasi. Pandangan Schmitt justru menjustifikasi otoritarianisme dalam politik serentak menegasikan pluralisme. Satu-satunya kemungkinan pluralisme bagi Schmitt adalah pluralisme negara. Tidak ada pluralisme dalam komunitas politis demokratis. Demokrasi selalu membutuhkan identitas demos yang homogen.

Interpretasi di atas kiranya dapat dibenarkan mengingat Schmitt pernah sangat antusias mendukung perebutan kekuasaan Nazi pada tahun 1933, menjustifikasi kejahatan Hitler, dan mendukung sikap anti-semitisme (Andreas Kalyvas, 2008: 80). Konstruksi teoretis Schmitt sendiri membenarkan sikapnya. Dalam pandangan Schmitt, demokrasi liberal adalah rezim yang tidak dapat bertahan (unviable regime) karena kedua prinsipnya bertentangan satu sama lain: liberalisme bertentangan dengan demokrasi dan demokrasi bertentangan dengan liberalisme. Selain itu, ia juga yakin bahwa pluralisme, yang dipahami sebagai pengakuan dan legitimasi konflik, tidak dapat diterima dalam masyarakat politis.
Menurut dia, jika konflik mendapat legitimiasi dalam masyarakat politis maka akan terjadi perang sipil (civil war). Bagi dia, inilah problem mendasar dari demokrasi liberal (Allan Dreyer Hansen \& André Sonnichsen, 2014: 267). ${ }^{1}$

Kedua, konversi dari musuh menjadi lawan berguna bagi pengakuan kontestasi tanpa konflik (Joss Hands, 2007: 90). Lawan yang Mouffe maksudkan ialah seseorang yang ide-idenya kita lawan, tetapi haknya untuk mempertahankan ide-ide itu tidak boleh dipertanyakan. Bagi Mouffe inilah arti

${ }^{1}$ Untuk memahami teori politik Schmitt, penting untuk mengetahui bahwa Schmitt merumuskan teorinya di tengah konteks Republik Weimar. Republik Weimar (bahasa Jerman: Weimarer Republik) adalah nama yang diberikan oleh sejarawan untuk republik parlementer yang didirikan tahun 1919 di Jerman untuk menggantikan bentuk pemerintahan kekaisaran. Disebut Republik Weimar karena konstitusi Jerman pada masa pasca Perang Dunia I ditulis di kota Weimar. Nama resminya adalah Deutsches Reich (kadang-kadang diterjemahkan sebagai Kekaisaran Jerman, tetapi Reich juga bisa berarti alam atau tingkat pemerintahan federal). Republik ini muncul dari Revolusi Jerman pada bulan November 1918. Pada tahun 1919, sebuah majelis nasional diselenggarakan di Weimar, di mana sebuah konstitusi baru bagi Reich Jerman ditulis, kemudian diadopsi pada tanggal 11 Agustus pada tahun yang sama. Jerman periode demokrasi liberal 'murtad' pada awal 1930-an, menuju ke pendakian dari NSDAP dan Adolf Hitler pada tahun 1933. Meskipun konstitusi 1919 tidak pernah secara resmi dicabut, tindakan hukum yang diambil oleh pemerintah Nazi pada bulan Februari dan Maret 1933, dikenal sebagai Gleichschaltung ("koordinasi") berarti bahwa pemerintah dapat mengatur bertentangan dengan konstitusi. Konstitusi menjadi tidak relevan. Dengan demikian, tahun 1933 biasanya dilihat sebagai akhir Republik Weimar dan awal Reich Ketiga Hitler. Bdk. https://id.wikipedia.org/wiki/Republik_Weimar, diakses pada 03 Maret 2020. 
yang sebenarnya dari toleransi liberaldemokratis. Toleransi semacam ini menempatkan lawan politik sebagai musuh yang legitim atau musuh yang ramah (Chantal Mouffe, 2000: 13,162). Inilah sebenarnya semangat yang harus dihidupi oleh para kontestan dalam Pilkada.

Ketiga, dengan memperkenalkan konsep lawan sebagai pengganti musuh, Mouffe membela "pluralisme agonistik". Tujuan utama dari gagasan "pluralisme agonistik" adalah pembentukan sebuah hegemoni kekuatan-kekuatan kiri. Sekumpulan kawan (oposisi) yang didefinisikan dalam relasi agonis bukanlah musuh melainkan lawan. Dengan demikian, radikalisme pluralisme agonistik terletak pada tujuannya untuk mengakui perbedaan dan hak berada setiap orang serta menjangkau sebanyak mungkin 'kawan', dengan tetap mempertahankan persaingan yang diperlukan dan perjuangan politis semata (Joss Hands, 2007: 90-91).

Setelah membedah konsepsi Mouffe tentang kategori kawan dan lawan, pertanyaannya apakah kategori itu mutlak atau permanen dalam politik? Jika disimpulkan berdasarkan seluruh penjelasan Mouffe, sebagai sebuah kategori politis, distingsi antara kawan dan lawan mutlak dalam politik. Kawan dan lawan merupakan kategori konstitutif dari yang politis. Yang politis tidak dapat dibentuk tanpa kategori spesifik ini. Namun, sebagai identitas politis, kategori kawan dan lawan itu bersifat kontingens. Sebagaimana setiap identitas sosial bersifat kontingens, identitas politis dalam distingsi kawan dan lawan pun bersifat kontingens. Sekelompok orang yang dalam Pilkada beberapa waktu lalu menjadi kawan politik misalnya, besok atau lusa bisa saja akan menjadi lawan politik; atau sebaliknya. Jadi, tidak ada kawan dan lawan yang abadi dalam politik. Politik hanya menjadi politik jika setiap kemungkinan rekonstruksi dan renegosiasi identitas politis terbuka lebar. Di sana ada upaya penyatuan dan pemisahan, perkumpulan dan peruraian. Justru di sinilah karakter estetik politik itu tampak.

\section{Demokrasi Agonistik}

Penjelasan di atas mengantar kita kepada inti gagasan yang hendak diusul dan dibela oleh Mouffe. Proyek Mouffe bertujuan untuk merancang suatu model agonistik demokrasi sebagai alternatif terhadap model demokrasi sebagai agregasi kepentingan dan demokrasi deliberatif (Rawls dan Habermas). Namun, sebelum melangkah lebih jauh, penting kiranya untuk mengklarifikasi beberapa kekeliruan umum berikut.

Dalam wawancara dengan Allan Dreyer Hansen \& André Sonnichsen, Mouffe mengingatkan beberapa kekeliruan umum dalam pembacaan atas karya Hegemony and Socialist Strategy dan The Democratic Paradox. Pertama, banyak orang keliru memahami gagasan demokrasi radikal yang diusung Mouffe dan Laclau dalam Hegemony and Socialist Strategy. Mereka memahami demokrasi radikal dan demokrasi liberal sebagai dua rezim yang sama sekali berbeda. Padahal, dalam The Dimensions of Radical Democracy (Mouffe, 1992), Mouffe sudah mengklarifikasi bahwa demokrasi radikal adalah radikalisasi demokrasi liberal. Pengimplementasiannya bagi Mouffe tidak butuh revolusi. Jika prinsip-prinsip etis politik dari demokrasi liberal - kebebasan dan kesetaraan untuk semua - diterima maka prinsip-prinsip yang lebih radikal tidak perlu dicari lagi. Persoalan dalam masyarakat demokratis liberal menurut Mouffe ialah prinsip-prinsip itu tidak dipraktikkan. Lebih lagi, kelompok kiri umumnya berpendapat bahwa prinsipprinsip itu palsu dan karena itu perlu ada perjuangan untuk menemukan sesuatu yang 
sama sekali baru. Posisi Mouffe justru sebaliknya. Menurut dia, strategi harus memaksa masyarakat untuk benar-benar mempraktikkan prinsip-prinsip itu. Bagi Mouffe, radikalisasi demokrasi harus dibayangkan sebagai kritik imanen, perjuangan, yang tidak menyiratkan pemutusan radikal tetapi dapat dilakukan melalui transformasi mendalam dari institusi demokrasi liberal yang ada. Mouffe yakin bahwa ini tentu akan memerlukan beberapa perubahan penting, beberapa lembaga perlu dibentuk, yang lain perlu diradikalisasi, tetapi intinya adalah bahwa mungkin untuk bekerja melalui lembaga-lembaga itu. Inilah yang disebut Gramsci sebagai perang posisi (Allan Dreyer Hansen \& André Sonnichsen, 2014: 265-267).

Lebih lanjut, Mouffe menegaskan bahwa dalam perspektif demokrasi radikal, atas dasar prinsip kebebasan dan kesetaraan bagi semua, politik demokratis tidak bisa dan tidak akan pernah bisa menghasilkan jenis 'pemerintahan yang koheren dan bersatu' dan masyarakat yang dapat direkonsiliasi dengan ontologi dominan liberal sepanjang Pencerahan. Politik dalam pandangan kaum demokrat radikal per se konfliktual. Oleh karena itu, visi kaum demokrat liberal yang ingin mencapai konsensus umum sudah pasti akan gagal (Joss Hands, 2007: 91). Demokrasi justru harus menyediakan arena di mana konflik dimungkinkan dan perbedaan pendapat dapat dihadapi ("Hearts, Minds and Radical Democracy", An Interview between Dave Castle and 'Chantal Mouffe and Ernesto Laclau', Juni 1, 1998, https://www.redpepper.org.uk/hearts-mindsand-radical-democracy/, diakses pada 1 November 2019).

Kedua, beberapa orang keliru memahami demokrasi agonistik dan demokrasi radikal. Mereka melihat keduanya sebagai satu hal yang sama. Mouffe menegaskan bahwa keduanya benar- benar berbeda dan terletak pada level yang berbeda pula. Demokrasi radikal adalah proyek politis (political project). Demokrasi agonistik adalah teori analitik (analytichal theory). Ia tidak memiliki muatan politis. Dalam paradigma demokrasi agonistik, demokrasi yang hidup membutuhkan perjuangan agonistik. Tujuan demokrasi bukan untuk mencapai konsensus final dan universal, melainkan untuk menciptakan kondisi-kondisi bagi konsensus konfliktual. Dalam perjuangan agonistik, orang akan membela berbagai proyek. Salah satu proyek itu, menurut Mouffe, adalah proyek demokrasi radikal. Proyek demokrasi radikal menekankan radikalisasi implementasi prinsip-prinsip liberal: kebebasan dan kesetaraan bagi semua. Namun, Mouffe mengambil pendirian ini bukan sebagai ahli teori, tetapi sebagai warga negara yang terlibat (proyek politis). Namun, ketika dia berbicara tentang demokrasi agonistik, dia berbicara sebagai ahli teori politik (teori analitik) (Allan Dreyer Hansen \& André Sonnichsen, 2014: 265-267).

Konsepsi Mouffe tentang pluralisme agonistik atau demokrasi agonistik berintensi menawarkan suatu alternatif yang menjaga ketidakberdamaian (irreconcilability) identitas adversarial tanpa menimbulkan permusuhan terbuka. Prasyaratnya ialah antagonisme harus dijinakkan. Kata Yunani 'agon' cukup memadai untuk menggambarkan penjinakan itu, di mana kontestasi yang legitim di antara para anggota suatu asosiasi politik dapat dicapai (Mathias Thaler, 2010:789-790). Dalam konteks ini istilah yang tepat untuk menggambarkan penjinakan antagonisme adalah "agonisme"2 (Allan Dreyer Hansen \& André Sonnichsen, 2014: 268).

\footnotetext{
${ }^{2}$ Term agonisme muncul dua kali dalam Michel Foucault, tetapi dalam cara yang berbeda. Kita juga menemukan term "agon" (kontes tanpa permusuhan) di dalam Friedrich Nietzsche, dan juga "agon" dalam bahasa Yunani. Selain itu,
} 
Transformasi antagonisme menjadi agonisme memiliki konsekuensi signifikan bagi pengakuan akan perbedaan-perbedaan (differences) dan legitimasi kontestasi tanpa kekerasan. Pengakuan ini membutuhkan sebuah upaya mobilisasi "hasrat-hasrat kolektif" (collective pasions) menuju desaign demokratis. Sebagai kekuatan penggerak dalam bidang politik, "hasrat kolektif" tidak dilenyapkan dari ruang publik demi tercapainya konsensus, tetapi dimobilisasi agar sesuai dengan design demokratis. Agar sesuai dengan design demokratis, ekspresi "hasrat kolektif" di ruang publik tidak boleh menghancurkan lawan (opponent). Itu berarti opponent tidak boleh dikonstruksi sebagai musuh (enemy), tetapi sebagai lawan (adversary). Tentang hal ini, Mouffe (2000: 102-103) menulis:

Antagonisme adalah perjuangan di antara musuh (enemies), sedangkan agonisme adalah perjuangan di antara lawan (adversaries). Oleh karena itu, kita dapat merumuskan kembali masalah kita dengan mengatakan bahwa tujuan politik demokrasi yang dibayangkan dari perspektif 'pluralisme agonistik' adalah

banyak juga orang lain yang menggunakan konsep agonisme, seperti Bill Connolly, Bonnie Honig, James Tully, dan Hannah Arendt. Pada umumnya mereka yang mengembangkan konsep agonisme itu dipengaruhi oleh Arendt dan Nietzsche. Honig dipengaruhi oleh Arendt; Connolly dipengaruhi oleh Nietzsche. Namun, Mouffe dipengaruhi oleh Carl Schmitt. Dalam pandangan Mouffe, Honig dan Connolly memahami agonisme sebagai "agonisme tanpa antagonisme". Sedangkan Mouffe memahami agonisme selalu dalam arti "agonisme dengan antagonisme". Dalam konteks ini, relasi agonistik dalam pandangan Mouffe berarti relasi antagonisme yang tersublimasi. Ia juga berbicara mengenai "relasi yang dijinakan", untuk menunjukkan antagonisme yang tidak tampak. untuk mengubah antagonisme menjadi agonisme. Ini membutuhkan penyediaan saluran melalui mana hasrat kolektif (collective passions) akan diberikan cara untuk mengekspresikan dirinya sendiri atas masalah-masalah yang, sementara memungkinkan kemungkinan identifikasi yang cukup, tidak akan membangun lawan (opponent) sebagai musuh (enemy), tetapi sebagai lawan (adversary). Perbedaan penting dengan model 'demokrasi deliberatif' adalah bahwa untuk 'pluralisme agonistik', tugas utama politik demokrasi bukanlah untuk menghilangkan hasrat (passion) dari ruang publik, untuk mencapai konsensus rasional yang mungkin tetapi untuk memobilisasi hasrat-hasrat rasional tersebut menuju desain demokratis.

Salah satu tesis sentral dari pluralisme agonistik ialah bahwa perdebatan agonistik merupakan suatu kondisi niscaya yang menjamin keberadaan demokrasi. Kekhasan demokrasi modern justru terletak pada pengakuan dan legitimasi konflik dan menolak untuk menekannya dengan tatanan otoriter (Chantal Mouffe, 2000: 103). Yang mau ditekankan di sini ialah konflik dan antagonisme merupakan suatu syarat kemungkinan bagi politik. Tanpa konflik, antagonisme, dan ketegangan-ketegangan sosial tidak ada politik. Model demokrasi agonistik ingin meradikalisasi konflik, antagonisme, dan ketegangan sosial itu sekaligus mentransformasikannya dengan cara-cara yang non-destruktif. Hal itu dilakukan dengan mentransformasi antagonisme-antagonisme sosial menjadi 
agonisme. Jika antagonisme mengacu pada kontestasi antara dua pihak yang bermusuhan (kawan/musuh) untuk menghacurkan satu sama lain, maka gagasan agonisme justru mengacu pada kontestasi antara dua pihak yang berlawanan (kawan/lawan) bukan untuk menghancurkan satu sama lain, melainkan justru tetap melindungi dan mengakui keabsahan posisi masing-masing (Hasruf Hanif, 2007: 133).

Sebagai antitesis terhadap model demokrasi deliberatif, model demokrasi agonistik ingin mengatasi sejumlah kekurangan yang ada dalam pendekatan deliberatif. Salah satu kelemahan utama pendekatan deliberatif menurut pengusung demokrasi agonistik ialah model ini tidak mampu mengakui dimensi antagonisme yang tak terhapuskan dalam politik yang ditimbulkan oleh pluralisme nilai-nilai. Hal itu terjadi karena mereka mempostulatkan ketersediaan ruang publik di mana kekuasaan akan dihilangkan dan konsensus rasional bisa diwujudkan (Chantal Mouffe, 2000: 98-99). Berseberangan dengan itu, model demokrasi agonistik menekankan radikalisasi diskursus. Demokrasi agonistik menyangkal ketersediaan prosedur-prosedur penentuan keputusan final yang rasional dan netral terhadap semua doktrin komprehensif. Keragaman permaianan bahasa (language games), ketersebaran kekuasan (the spread of power), dan pluralitas nilai-nilai membuat cita-cita untuk mencapai keputusan final tidak mungkin terwujud. Demokrasi memiliki karakter ketakterputusan (undecidability). Dalam demokrasi setiap keputusan selalu terbuka untuk diperdebatkan dan dipersoalkan.

Lebih lanjut, pengusung model demokrasi agonistik, terutama Mouffe, menekankan bahwa cita-cita demokrasi pluralis untuk mencapai konsensus rasional di ruang publik adalah ilusi. Konsensus semacam itu tidak bisa ada. Harus diakui bahwa setiap konsensus ada sebagai hasil sementara dari hegemoni sementara dan sebagai stabilisasi kekuasaan. Selain itu, setiap konsensus selalu memerlukan tindakan eksklusi. Bagi Mouffe (2000: 104), 'gagasan bahwa kekuasaan dapat dibubarkan melalui debat rasional dan bahwa legitimasi dapat didasarkan pada rasionalitas murni adalah ilusi yang dapat membahayakan institusi demokrasi.'

Dari penjelasan di atas, tampaknya Mouffe menolak konsensus politis secara radikal. Jika kesimpulan ini benar, apakah tidak membahayakan tatanan demokratis jika disensus politis berkembang drastis dan berubah menjadi konflik berkepanjangan? (Otto Gusti Madung, 2017: 135). Dalam Democratic Politics and Agonistic Pluralism (2009: 10) dan On the Political (2005: 31), Mouffe menunjukan bahwa pada takaran tertentu konsensus tetap dibutuhkan.

Ia menulis:

Sementara konsensus tidak perlu diragukan, itu harus disertai dengan perbedaan pendapat. Konsensus diperlukan pada lembaga-lembaga yang merupakan konstitutif demokrasi dan pada nilai-nilai etis-politik yang harus menginformasikan asosiasi politik - kebebasan dan kesetaraan untuk semua - tetapi akan selalu ada ketidaksepakatan mengenai makna nilai-nilai itu dan cara mereka diimplementasikan. Dalam demokrasi pluralis, pertikaian semacam itu tidak hanya sah tetapi juga perlu. Mereka memungkinkan berbagai bentuk identifikasi kewarganegaraan dan merupakan bagian dari politik demokratis. 
Di sini tampak bahwa model demokrasi disensus atau demokrasi agonistik pada dasarnya tetap berpijak pada konsensus tentang nilai-nilai atau prinsipprinsip dasar dan prosedur demokratis. Pengakuan akan kewajiban normatif kolektif selanjutnya memungkinkan terjadinya konfrontasi agonistik dalam suasana saling pengakuan meskipun terdapat pertentangan dan perdebatan (Otto Gusti Madung, 2017: 135).

\section{Spirit Baru Pasca-Pilkada}

Setelah membahas beberapa konsep dasar teori Chantal Mouffe tentang politik dan demokrasi agonistik, dalam konteks Pilkada serentak 2020, pertanyaan yang perlu diajukan ialah spirit apa yang perlu dihidupi setelah pesta demokrasi musiman itu selesai digelar? Atau dalam formulasi yang lain, apa implikasi teori Chantal Mouffe di atas untuk keberlangsungan demokrasi pasca-Pilkada?

Sebagaimana ditegaskan pada bagian awal tulisan ini, demokrasi itu butuh konfrontasi. Konfrontasi itu tidak hanya berhenti pada saat proses Pilkada berlangsung. Setelah Pilkada, konfrontasi tetap dibutuhkan. Ideal mencapai kesejahteraan umum tidak bisa hanya mengandalkan kolaborasi, tetapi juga konfrontasi. Konfrontasi itu tampak dalam pertentangan pendapat antara pemegang tampuk kekuasaan dan oposisi. Yang diperdebatkan di sini bukanlah masalahmasalah privat pemegang kekuasaan, melainkan masalah-masalah yang berhubungan dengan hajat hidup orang banyak. Dengan demikian, tidak penting dihadirkan di ruang publik diskusi dan perdebatan seputar pejabat publik yang berselingkuh dengan artis $\mathrm{A}$ atau wanita $\mathrm{B}$ atau laki-laki C. Itu tidak berfaedah sebagai diskursus politik.
Untuk menjaga agar konfrontasi dalam politik tetap hidup, demokrasi butuh oposisi. Oposisi adalah lawan politik yang posisinya harus dilindungi. Kehadiran oposisi itu penting agar fungsi kontrol tetap berjalan. Dalam konteks ini, pasca-Pilkada digelar, oposisi atau lawan-lawan politik yang kalah dalam kontestasi Pilkada diharapkan tetap menjaga komitmennya sebagai oposisi pemerintah. Di sini, penulis tidak menganjurkan untuk mengadopsi gaya politik penjinakan a la Jokowi - kendati identitas politis itu bersifat kontingens. Gaya politik penjinakan semacam itu bagi penulis hanya akan mematikan karakter political serta melumpuhkan fungsi kontrol oposisi.

Spirit lain yang perlu dibangun setelah Pilkada ialah merawat keakraban sebagai warga negara. Keakraban sebagai warga negara itu dirawat di ruang-ruang diskursus dan dalam komunikasi serta relasi seharihari. Sebagai warga negara, kita harus tetap saling menerima, menghormati, dan mengakui perbedaan satu sama lain. Polarisasi akibat Pilkada tidak mesti mematikan keakraban berwarga negara. Jika semangat ini dihidupi proses demokrasi akan tetap berjalan setelah Pilkada. Sebab kemungkinan untuk munculnya diskursusdiskursus politik yang berbobot di ruang publik tetap terbuka lebar. Kendati demikian, diskursus-diskursus di ruang publik itu tidak harus bertujuan mencapai konsensus. Dasarnya, demokrasi tidak selalu bertujuan untuk mencapai kesepakatan final dan universal. Demokrasi juga harus tetap mempertahankan dimensi konfliktual, agonistik, dan disensusnya. Upaya mempertahankan dimensi konfliktual, agonistik, dan disensus demokrasi bertujuan untuk mengembalikan pluralitas narasinarasi kecil yang tersubordinasi oleh narasinarasi besar yang diyakini sebagai konsensus final dan universal. 


\section{Penutup}

Sebagai salah satu prestasi desentralisasi, Pilkada merupakan momentum untuk membangun kekuatan politik untuk mencapai kesejahteraan umum. Pilkada dalam konteks ini merupakan sistem yang memberi peluang kepada rakyat untuk memilih pemimpin mereka secara langsung melalui proses pemilihan yang kompetitif. Para pemimpin yang terpilih dalam proses ini diharapkan dapat mengorganisasi kekuasaan untuk mencapai kesejahteraan umum. Untuk mewujudkan kesejahteraan umum, pemimpin tidak cukup mengandalkan kolaborasi, tetapi juga butuh pertentangan atau konfrontasi. Konfrontasi yang diharapkan dalam politik demokrasi ialah konfrontasi agonistik. Konfrontasi agonistik mensyaratkan penempatan lawan bukan sebagai musuh yang segera dihabisi, melainkan sebagai lawan yang posisinya harus dilindungi. Kita boleh saja berbeda pendapat dengannya, tetapi haknya untuk berbeda pendapat dengan kita mesti dilindungi. Ini adalah tuntutan mutlak. Tuntutan ini bertujuan untuk mencegah konflik dan perbedaan pendapat menjelma dalam cara-cara yang destruktif. Komitmen untuk melaksanakan tuntutan itu merupakan syarat mutlak bagi perwujudan diskursus yang radikal.

\section{Daftar Pustaka}

Adian, Donny Gahral. 2010. Konstitusi dan Substansi Demokrasi. Jakarta: Demos - Lembaga Kajian Demokrasi dan Hak Asasi.

Hands, Joss. 2007. "Between Agonistic and Deliberative Politics: Towards a Radical E-Democracy", dalam L. Dahlberg \& E. Siapera (Eds.). The
Internet and Radical Democracy. Basingstoke: Palgrave.

Hanif, Hasruf. 2007. "Antagonisme Sosial, Diskonsensus, dan Rantai Ekuivalensi: Menegaskan Kembali Urgensi Model Demokrasi Agonistik". Jurnal Ilmu Sosial dan Ilmu Politik, Vol. 11, No. 1 , Juli.

Hansen, Allan Dreyer \& André Sonnichsen. 2014. "Radical Democracy, Agonism and the Limits of Pluralism: an Interview with Chantal Mouffe". Distinktion: Scandinavian Journal of Social Theory, Vol. 15, No. 3, Agustus.

"Hearts, Minds and Radical Democracy". An Interview between Dave Castle and 'Chantal Mouffe and Ernesto Laclau', Juni 1, 1998, https://www.redpepper.org.uk/heartsminds-and-radical-democracy/, diakses pada 1 November 2019.

https://id.wikipedia.org/wiki/Republik_Wei mar, diakses pada 03 Maret 2020.

Kalyvas, Andreas. 2008. Democracy and the Politics of the Extraordinary - Max Weber, Carl Schmitt, and Hannah Arendt. Cambridge, New York, Melbourne, Madrid, Cape Town, Singapore, Sāo Paulo: Cambridge University Press.

Madung, Otto Gusti. 2017. PostSekularisme, Toleransi, dan Demokrasi. Maumere: Penerbit Ledalero.

Mouffe, Chantal. 2000. The Democratic Paradox. London - New York: Verso. 
------. 2005. On the Political - Thingking in Action. Abingdon: Routledge.

-------. 2009. "Democratic Politics and Agonistic Pluralism". Seminario interdisciplinar $\mathrm{O}(\mathrm{s})$ Sentido(s) $\mathrm{Da}(\mathrm{s})$ Cultura(s) Coordinando Por Ramón Maiz, Venres, 18 Desember.

Schmitt, Carl. 2007. The Concept of the Political. Trans. George Schwab. Chicgo dan London: The University of Chicago Press.

Thaler, Mathias. 2010. "The Illusion of Purity: Chantal Mouffe's Realist Critique of Cosmopolitanism". Philosophy and Social Criticism, 36:7. 